\title{
A dialética nos escritos do círculo de Bakhtin
}

\section{The dialectic in the Bakhtin's Circle writings}

Daniela Cardoso

Atua como docente na Faculdade João Paulo II Passo Fundo e como revisora Fundo. Este trabalho é parte da tese de doutoramento apresentada ao PPGL da PUCRS.

E-mail: dani.cardoso@upf.b
RESUMO: Este estudo realiza um cotejamento dos escritos do Círculo de Bakhtin acerca da linguagem com os pressupostos do materialismo dialético apresentados por Marx e Engels, especificamente, nas obras Ideologia alemã e nos Manuscritos econômico-filosóficos. Com isso, reconhece-se o caráter dialético-materialista das propostas conceituais do Círculo de Bakhtin para definir a linguagem. Entende-se que, na linguagem, há uma relação de influência recíproca entre a alteridade, a dialogicidade e a ideologia, conformadas no enunciado concreto e, em última instância, no gênero discursivo. Assim, o texto evidencia que as elaborações do Círculo acerca do fenômeno linguístico são manifestações de uma concepção dialético-materialista da realidade/objeto investigado.

Palavras-chave: Linguagem; Alteridade; Dialogicidade; Ideologia; Dialética.

ABSTRACT: This study aims to accomplish a readback of Bakhtin Circle writings about language with dialectical assumptions presented by Marx and Engels in The Germany Ideology and Economic and Philosofical Manuscript. It seeks to recognize the dialectic-materialist character of the Bakhtin Circle conceptual proposals to define language. It is understood that in language, there is a mutual influence relation among otherness, dialogism and ideology, in the concrete enunciation and ultimately in the speech genre. The hypothesis that guides this study is that the elaborations of the Circle about the linguistic phenomenon are manifestations of a dialectical-materialist idea about the investigated reality/object.

KEYworDS: Language; Otherness; Dialogism; Ideology; Dialectic. 


\section{Introdução}

$\mathrm{E}$ ste artigo apresenta apontamentos pelos quais se torna possível evidenciar os pressupostos dialético-materialistas na abordagem Bakhtiniana da linguagem. Esclarecemos de antemão a não preocupação com aspectos autorais na análise das obras, de forma que a observação se volta aos escritos em aspectos conceituais, motivo pelo qual referenciamos os autores conforme se apresentam nos originais.

As obras do Círculo de Bakhtin constituem objeto de diversas investigações científicas, em diferentes campos do conhecimento, como linguística, literatura, filosofia, educação e psicologia. No campo dos estudos linguísticos, o estudo dos gêneros discursivos, da alteridade, da dialogicidade, entre outras noções, vem sendo foco de investigações voltadas, sobretudo, à abordagem da produção textual e a questões semânticas da linguagem. Tais aspectos têm ligado a pesquisa dos postulados do Círculo ao ensino de língua, o que acaba por ampliar o escopo em torno das pesquisas na área. Em decorrência, talvez, dessa amplitude de estudos, tem-se o surgimento de interpretações que expressam concepções teóricas nem sempre coerentes com os conceitos elaborados pelo Círculo.

Desde a noção de língua, perpassando pelas demais categorias postuladas na obra do Círculo, não se está diante de objetos com abordagem homogênea, mas de distintas concepções que tomam por base correntes teóricas e pressupostos epistemológicos diversos.

Neste texto, propomos evidenciar, em partes, a relação dialética existente entre as dimensões elencadas e a necessária unidade e influência recíproca das partes para que se esteja de fato frente ao objeto linguagem em uma concepção bakhtiniana. A investigação busca por uma fundamentação epistemológica que nos possibilite uma compreensão mais verdadeira do objeto proposto nas obras do Círculo de Bakhtin ao tratar da linguagem.

Para isso, apresentamos as reflexões e os conceitos elaborados por Marx e Engels que se aproximam da compreensão de linguagem do Círculo. Iniciamos pela obra Ideologia alemã, realizando, à luz dos conceitos encontrados nessa obra, uma releitura de textos do Círculo de Bakhtin, a saber: Para uma filosofia do ato; Estética da criação verbal; Marxismo e filosofia da linguagem: problemas fundamentais do método sociológico na ciência da linguagem; Problemas da poética de Dostoiévski; Questões de literatura e de estética: a teoria do romance. Antes, esclarecemos os conceitos fundadores da dialética materialista, interesse deste estudo.

\section{Tudo se relaciona}

A concepção totalizante da natureza, enquanto um todo coerente em que "objetos e fenômenos são ligados entre si condicionando-se reciprocamente". o fundamental é entender que o exame das partes, isoladas, objeto-fenômeno não manifesta a realidade, posto que o todo se cria na interação das partes (Kosik, p. 24, apud Gadotti, 1995). O sentido das coisas está somente no aspecto totalizante.

\section{Tudo se transforma}

A dialética concebe o movimento como qualidade inerente a todas as coisas. A sociedade, a natureza são sempre inacabadas, em processo de transformação que encontra sua causa na luta interna de cada fenômeno da realidade. Essa é uma lei universal.

Essa lei dá conta do fato de que o movimento geral da realidade faz sentido, quer dizer, não é absurdo, não se esgota em contradições irracionais, inteligíveis, nem se perde na eterna repetição do conflito entre teses e antíteses, entre afirmações e negações. A afirmação engendra necessariamente sua negação [...]. (Konder, p. 59) 


\section{Mudança qualitativa}

Este princípio demonstra que a chegada do novo não pode ser resultado de repetição circular. $\mathrm{O}$ acúmulo de mudanças quantitativas produz o novo, a mudança qualitativa.

\section{Unidade e luta dos contrários}

Eis aí a lei fundamental da dialética: no interior de cada coisa coexistem "forças opostas tendendo simultaneamente à unidade e à oposição" (Gadotti, 1995, p. 26). Em outras palavras, a contradição é inerente a todas as coisas, sejam materiais ou espirituais e isso é que faz a transformação ocorrer.

Em suma, pode-se dizer que um raciocínio dialético segue as premissas de que o fenômeno é resultado da relação que este estabelece com outros fenômenos formando uma totalidade de determinações recíprocas de tal forma que se constitui em movimento constante e infinito, gerado pela contradição, ou luta de contrários, característica intrínseca de todo e qualquer fenômeno, e que deve resultar em uma mudança qualitativa do fenômeno.

Seguindo as assertivas feitas, conclui-se que o pensamento dialético exige a inserção do fenômeno em uma realidade ampliada das relações possíveis, o que no caso da linguagem, fenômeno intrinsecamente interativo, implica uma abordagem da própria história da humanidade. Dessa forma, somente se poderia pensar em uma concepção dialética da história para embasar tal raciocínio, o que justificaria as tentativas de distanciar as abordagens do Círculo para o fenômeno linguagem das elaborações materialistamarxistas, haja vista o critério de classe assumido pelos autores da proposta materialista-dialética de análise da realidade.

Retomando a discussão proposta, acerca da obra - Ideologia alemã-, vale lembrarmos que sua publicação primeira data de 1932, em Obras completas, de Marx e Engels. Apesar de ter sido escrita entre os anos de 1845-46, não se pode afirmar se Bakhtin/Volochinov teve, ou não, contato com esses escritos antes de elaborar seu texto Marxismo e filosofia da linguagem, datado de 1929, o que torna a análise aqui proposta instigante, porque verificará pontos entre obras que se pode dizer "contemporâneas de escrita".

Também propomos fazer uma reflexão em torno das abordagens apresentadas nos Manuscritos econômicos, por entender que esta obra é tão determinante na formação do signo ideológico marxismo quanto à anteriormente citada. Além disso, abordamos conceitos importantes para serem pensados nas obras do Círculo, trazidos por Lucáks (1960), Kosik (1976).

\section{0 sentido construído na relação dos contrários}

Destacamos, inicialmente, a Marxismo e filosofia da linguagem: problemas fundamentais do método sociológico na ciência da linguagem (BAKHTIN/ VOLOCHINOV, 1929/2010). Nesse texto, Bakhtin/Volochinov (1929/2010) apresenta a proposta de que o sentido só pode ser alcançado com base na compreensão do signo, ideológico por definição, abordado do ponto de vista de suas ligações sociais, determinadas pela organização da vida cotidiana dos seres. Tais aspectos precisam se manifestar em uma dada situação de interação, a qual deve compor de igual forma a análise.

Sob esse enfoque, conteúdo e forma ganham abordagem dialética, já que são fenômenos observáveis na práxis cotidiana dos homens, em suas relações objetivas/subjetivas, e que refletem e refratam o próprio ser. As formas de expressão correspondentes às diversas esferas de organização social exprimem as contradições da sociedade porque refletem uma dada consciência de classe, a psicologia do corpo social, e que se encontra refratada pela ideologia dominante, sempre presente na linha de diálogo em que se produz uma enunciação. 
Um aspecto bastante forte nos escritos em estudo é o dialogismo intrínseco à linguagem. A obra Marxismo e filosofia da linguagem propõe que até mesmo as formas mínimas do discurso interior constituem enunciações completas que se assemelham a réplicas de um diálogo. Argumenta-se que a única maneira de resolver o problema da delimitação fronteiriça entre o psíquico e o ideológico seria o estudo do território singular que os engloba: o signo ideológico. Nesse aspecto, a ligação com uma abordagem dialética de análise aparece reforçada no referido texto:

A relação dialética entre o objetivo, ato de fala, enunciado, e o subjetivo, caráter interpretativo do ser humano que logo se fará concreto constitui uma relação dialógica imbricada de ideologia. Ainda na mesma obra, Marxismo e filosofia da linguagem, há a objetivação da concepção dialética ao tratar "marxismo" como signo ideológico. Tal signo não se mostra unívoco, estável, mas está sempre carregado de aspectos valorativos, tornando-se ele mesmo uma arena de conflitos, o que na teoria de Bakhtin/Volochinov se denomina como "índices de valor contraditórios" (BAKHTIN/VOLOCHINOV 1929/2010, p. 47).

Ao pensarmos no conceito de dialogicidade, tão reivindicado pelos leitores do Círculo, a própria tentativa de monologizar o signo marxismo torna-se contraditória, o que em princípio pode ser indícios de uma interpretação unilateral do próprio signo. Qualquer signo ideológico tem sempre duas abordagens que só podem ser percebidas na luta de classes.

Na realidade todo o signo ideológico tem, como Jano, duas faces. Toda crítica viva tornar-se elogio, toda verdade viva não pode deixar de parecer para alguns a maior das mentiras. Esta dialética interna do signo não se revela inteiramente a não ser nas épocas de crise social e de comoção revolucionária (BAKHTIN/ VOLOCHINOV 1929/2010, p. 48).

Em momentos de crise social, pode-se observar de forma mais aparente as oposições internas em cada signo ideológico. Isso ocorre porque a efervescência social de momentos desses períodos exige novas interpretações de realidades que se alteram com rapidez, em busca de soluções para situações nas quais o ser sujeito social não pode permanecer.

Ao propor a concepção de trabalho alienado nos Manuscritos econômicosfilosóficos, Marx discorre sobre a relação homem-natureza, a atividade humana objetivada no trabalho e explica pela relação com os outros, a formação da consciência (MARX, 2010). Marx analisa a consciência humana tomando por base as unidades conteúdo/forma e concreto/abstrato, em uma abordagem dialética que se opõe à proposta de Hegel, no que diz respeito à concepção idealista deste autor. Enquanto Hegel afirma a centralidade do pensamento, Marx propõe a centralidade do plano material, concreto, como se pode verificar em Crítica da dialética e da filosofia de Hegel, no Terceiro Manuscrito.

Essas mesmas unidades aparecem no texto de Marxismo e filosofia da linguagem, ao abordar a psicologia do corpo social, em especial, na ideologia do cotidiano, destacando na formação da consciência o imperativo dos tipos e formas de discurso. Em outras palavras, discute-se como os temas versam em formas de discurso (BAKHTIN/VOLOCHINOV, 1929/2010, p .42). Nessa esteira, o texto citado destaca a relação recíproca entre a estrutura, a produção e as formas ideológicas derivadas dos meios de produção que se encontram refletidos na comunicação.

Assim, os autores assumem que cada tema de todos os atos de fala nascem antes nas relações sociais, as quais, por sua vez, acontecem em determinadas condições objetivas de existência. Os atos de fala ocorrem sempre em decorrência de comunicação verbal que implica a ação humana na realidade em que se insere o sujeito e não pode deixar de refletir uma relação possível concretamente na realidade, ou seja, não se pode pensar um dado enunciado abstratamente, distante das influências axiológicas do lugar ocupado pelo sujeito. 
A interação verbal ocorre vinculada à realidade, justamente porque constitui uma forma de ação humana, seja sobre a natureza ou em relação com os sujeitos inseridos em um dado grupo social. Por essa proximidade com as condições concretas, é que se encontram nas formas de interação qualquer aspecto envolvido na esfera social, seja de permanência ou de mudança nesse âmbito. É nesse sentido que os autores vão propor o estudo dos gêneros discursivos, como reflexo do aspecto social no individual, em termos linguísticos.

Bakhtin/Volochinov apresenta a ideia de que há certa estabilidade na conformação dos discursos que se vinculam à estabilidade própria da sociedade ou da comunicação. Assim, a comunicação socioideológica encontra formas mais ou menos estáveis, o que chama de gênero discursivo. Essa forma se organiza em torno da relação do tema, de forma que cada grupo de temas tem sua forma, gênero.

Ao estudo do enunciado são trazidos conceitos que procuram representar propriedades inerentes, marcas da natureza heterogênea do objeto em estudo, a saber: alteridade, dialogismo e ideologia. A relação de influência recíproca das três dimensões básicas - alteridade, dialogicidade e ideologia - delimita os estudos e exige a compreensão de outros constructos teóricos ou categorias de análise que sejam capazes de demonstrar na materialidade da linguagem tantos aspectos envolvidos no fenômeno, dado que o considere dialético.

Acreditamos que a centralidade dos conceitos de alteridade, dialogismo e ideologia, os quais estabelecem outras inúmeras relações entre conceituações diversas de igual importância nas obras do Círculo, torna-se uma possibilidade de estudos bastante producente. Por isso, passamos a demonstrar o possível vínculo entre a proposta de Bakthin para cada um desses conceitos e as elaborações de Marx e Engels.

\section{A constituição alteritária do enunciado}

A alteridade constitui a base primeira do enunciado, não porque seja mais importante do que as demais relações expressas nessa unidade, mas porque se pode pensar como início mesmo da materialização do fenômeno em estudo. Escolhemos, por isso, iniciar o texto também por essa dimensão que demarca a própria existência do enunciado, em conformidade com a existência social da humanidade.

Em Idelologia alemã, Marx e Engels procuram explicar como de fato se dá a própria existência humana e a constituição dos atos históricos da humanidade, o que parece ser importante para a proposta deste trabalho. A discussão apresentada pelos autores retoma as origens do ato humano, trazendo a noção de que a formação da sociedade só ocorre, ocorreu, devido ao fato de que o homem precisa satisfazer certas necessidades. 0 meio de satisfação das necessidades humanas mais básicas, garantindo a própria vida, é uma dada intervenção na natureza, uma atividade, o trabalho.

A própria satisfação das necessidades primeiras dá origem a novas necessidades e isso constitui o ato histórico de formação da sociedade. Esses mesmos homens que dão conta de suas necessidades primeiras, gerando novas necessidades, também dão origem a novas vidas, na formação da família, a qual constitui, inicialmente, a única relação social. Mas Marx e Engels destacam que esse processo é um contínuo, ampliando por isso as relações sociais em si.

A produção da vida, tanto da própria, no trabalho, quanto da alheia, na procriação, aparece desde já como uma relação dupla -, de um lado, como relação natural, de outro como relação social-, social no sentido de que por ela se entende a cooperação de vários indivíduos, sejam quais forem as condições, o modo e a finalidade (MARX E ENGELS, 2012, p. 33). 
Os autores, ao apresentarem a ontologia do trabalho como base primeira de suas elaborações, que são reconhecidamente o começo da conceituação da dialética materialista, assumem que o trabalho, como práxis, é o determinante na formação da consciência. As condições concretas e materiais da existência, entendidas aqui como as relações de trabalho do homem que levam à constituição de uma sociedade, que tem por base uma dada divisão do trabalho, estruturam a consciência.

Para eles, a linguagem constitui a materialidade da consciência e, por isso, também a linguagem encontra sua base material na práxis humana, nas formas e nas relações de trabalho e organização social. Pensada de forma dialética, a relação do homem com seu trabalho constitui-se como atividade, sendo uma ação do homem com a natureza e uma interação entre ele e os outros homens. A vida do homem é fundamentada nessa relação, denominada pelo marxismo de práxis.

Somente agora, [...] descobrimos que o homem tem também "consciência". Mas esta também não é desde seu início, consciência 'pura'. 0 'espírito' sofre, desde o início, a maldição de estar 'contaminado' pela matéria, que, aqui, se manifesta sob a forma de camadas de ar em movimento, de sons, em suma, sob a forma de linguagem (MARX E ENGELS, 2012, p. 37).

Assim, o que se depreende é que a linguagem, da mesma forma que a consciência, se forja na relação com o outro e com a natureza, de tal forma que se evidencia a alteridade intrínseca da linguagem, como ato humano, nas definições de Marx e Engels (2012).

Ao referenciar o modo de produção da vida humana, esses autores asseveram que o próprio indivíduo torna-se o seu ato de produção e sua produção em si, ou ele é o que consegue exteriorizar nessa práxis humana de existência.
Esse modo de produção não deve ser considerado meramente sob o aspecto de ser a reprodução da existência física dos indivíduos. Ele é, muito mais, uma forma determinada de sua atividade, uma forma determinada de exteriorizar sua vida, um determinado modo de vidas desses indivíduos. Tal como os indivíduos exteriorizam sua vida, assim são eles. [...] 0 que os indivíduos são, portanto depende das condições materiais de sua produção MARX E ENGELS, 2012, p. 87).

Uma compreensão semelhante a essa parece ser desenvolvida sobre as bases filosóficas da linguagem em Para uma filosofia do ato (PFA). Nesse texto ${ }^{1}$, o autor considera que o ato se constitui do pensamento humano assinado por um sujeito, o que torna tal pensamento válido. 0 autor argumenta que a assinatura é a expressão de uma posição, estando longe de constituir expressão subjetiva. Assinar é esclarecer um pensamento com abordagens que só podem ser vistas ou ditas a partir do lugar social que se ocupa.

Assinatura, nessa perspectiva, significa não fugir de expressar aquilo que só pode ser visto pela singularidade. Ao assinar um pensamento, tornando ato, o sujeito se declara em determinado tempo e espaço, assumindo-se como ser real que se apropria de seu contexto. Por isso, se pode dizer que o ato pensado por Bakhtin é também manifestação de alteridade, visto que se faz em confronto com os outros sujeitos.

Bakhtin define o ato de pensar como uma "atitude imperativa da consciência", algo do qual o ser humano pouco tem em se abster, tornandose a própria humanização do ser.

Aqui está o ponto de origem da ação responsável e de todas as categorias do dever concreto, único e necessário. Eu, também, existo [et ego sum] (em toda a plenitude emocional-volitiva, realizadora [postupochnaia] dessa afirmação) realmente - no todo, e assumo a obrigação de dizer esta palavra. Eu também participo do Ser de uma maneira única e irrepetível: eu ocupo um lugar no Ser único e irrepetível, um lugar que não pode ser tomado por ninguém mais e que é impenetrável a qualquer outra pessoa. [...] Aquilo que pode ser feito por mim não pode nunca ser feito por ninguém mais (BAKHTIN, 1920/1924, 2003, p. 58

BAKHTIN, Michail. Para uma filosofia do ato. 1920-1924, 2003. 
Bakhtin propõe como questão central em PFA a elucidação da dimensão ética de um pensamento teórico. Para tanto, aborda duas verdades: a instina e a pravda. $\mathrm{O}$ pensador propõe o termo russo istina para designar a verdade de um conteúdo teórico, mas assevera que isso não garante a esta teoria a dimensão ética. A ética de um pensamento só pode surgir no ato de pensar que implica um sujeito, único. Assim, no campo da abstração, a teoria obriga-se apenas a ser verdadeira em seu conteúdo. Uma dada teoria, que seja verdadeira, é pensada por alguém único e singular e se caracteriza, por isso, pela ética. Somente ao ponto que vire ética é que a teoria verdadeira se completa em pravda. Se não temos o ato de pensar de um sujeito, o conhecimento é parcial e abstrato. É pelo ato concreto, ético e responsável, que o mundo da cultura e o mundo da vida se tocam mutuamente.

$\mathrm{O}$ ato, para Bakhtin, é criação, em que se concretiza o pensamento teórica e culturalmente. A característica essencial desse conceito é constituir-se, de assinatura, de posicionar-se, portanto de alteridade, pois o sujeito pensa e assume seu pensamento perante o outro; é uma atitude ética em que o sujeito se arrisca, sendo convocado a pensar; é determinado, não pode ser fortuito, pois do lugar onde o sujeito está só poderia pensar o pensamento mesmo que apresenta; é a única forma de superação da divisão entre a cultura e a vida, nele se condensam teoria e prática, como na práxis.

Em sua responsabilidade, o ato coloca diante de si sua própria verdade [pravda] como algo-a-ser-alcançado - uma verdade que une os momentos subjetivo e psicológico, exatamente como une o momento do que é universal (válido universalmente) e o momento do que é individual (real) BAKHTIN, 1920/1924, 2003, p. 47).

Bakhtin traz a ideia de não-alibi no ser, mostrando que não há para os seres humanos nenhuma justificativa para desreponsabilizá-los de seus atos. A responsabilidade advém da própria existência singular de cada indivíduo; se existe, não pode se eximir de tal responsabilidade. A posição no mundo, a própria existência em tempo e espaço confere responsabilidade ao sujeito; o ser acontecimento que se realiza como sujeito não torna possível uma abstenção do ato. 0 sujeito que não assume esta responsabilidade abstémse de sentido.

Esse reconhecimento da unicidade da minha participação no Ser é a fundação real e efetiva da minha vida e minha ação realizada. Minha ação ativa afirma implícita sua própria singularidade e insubstituibilidade dentro do todo do Ser, e nesse sentido ela é colocada, de dentro de si, em imediata proximidade com as fronteiras desse todo e orientada dentro dele como um todo. Isso não é simplesmente uma afirmação de mim mesmo ou simplesmente uma afirmação do Ser real, mas uma não fundida mas individida afirmação de mim mesmo no Ser: eu participo no Ser como seu único ator (BAKHTIN, 1920/1924, 2003, p. 59)

A impossibilidade da indiferença garante a permanente renovação do ser, que se altera e se constitui pelo outro, como pressupõe a alteridade. Dessa forma, a alteridade é parte constituidora do sentido do ser no mundo, de tal forma que o sentido não pode ser compreendido como expressão de singularidade, mas como produto do pensamento-ato. Assim, o sentido só pode se formar na relação com o outro. Reafirmamos que é na articulação entre sujeito e cultura, no pensamento-ato que se torna possível o sentido do ser, enquanto participante da cultura, da história, da realidade. É assim que o sentido do ser se dá na participação consciente e responsável na cultura (BAKHTIN, 1920/1924, 2003).

A necessidade de um ato-pensamento é, para Bakhtin, uma questão ética de existência do sujeito. Não diz respeito a uma necessidade lógica, como no caso de uma teoria. Como não se trata de uma necessidade mecânica, trata-se de "necessitância2". O dever de pensar implica uma impossibilidade

2 Neologismo que tomou por base a tradução francesa da obra e se mantém na versão consultada. 
de não pensar, consequência da posição ocupada em uma situação real de existência concreta. Bakhtin busca uma relação entre ação e conteúdo ao afirmar que "Cada pensamento meu, junto com o seu conteúdo, é um ato ou ação que realizo - meu próprio ato ou ação individualmente responsável. É um de todos aqueles que fazem de minha vida única e inteira [...]" (BAKHTIN, 1920/1924, 2003, p. 22). Assim o autor mostra que o ato humano é um pensamento que constitui um todo do qual faz parte o conteúdo-sentido e a presença deste conteúdo em uma dada existência/consciência real.

Em PFA, Bakhtin reconhece que é possível tomar-se "um pensamento como um juízo universalmente válido quando se toma o momento do conteúdo-sentido abstratamente. Nesse caso o aspecto histórico-individual é completamente imaterial." A validade de um juízo universalmente valido pertence à unidade teórica. A validade de um ato (pensamento concreto) deve incluir o momento mesmo da validação teórica, mas a validade teórica se esgota em si. A individualidade do sujeito pensante, pelo seu ato responsável, não se faz presente no "juízo teoricamente valido." BAKHTIN, 1920/1924, 2003, p. 21). Assinatura é assumir-se como sujeito em um dado espaço-tempo, portanto ser real e concreto que transforma o seu contexto quando o assume em ato.

A constituição alteritária do enunciado, como ato concreto, pode ser observada tanto na assertiva de Marx e Engels de que a consciência se forja na interação social e se encontra materializada na linguagem, como nas afirmativas de Bakhtin, de que a linguagem é ato singular, carregado de valor, determinado pelo tempo e espaço, de onde o sujeito se projeta em sua "assinatura." A alteridade está na base de formação da consciência e não é negada na continuação do processo de formação de novas consciências, quando da assinatura do pensamento.

Além disso, Marx reconhece a constituição do próprio indivíduo naquilo que ele externaliza, seja na produção da vida em termos técnicos, seja no ato de comunicação, que é uma representação do real. Marx e Engels (2012) afirmam que a produção aparece com o aumento da população. Para eles o intercâmbio é intrínseco ao ato de produzir e condicionado em sua forma pela produção em si. A alteridade presente no ato de Bakhtin parece relacionar-se diretamente com a práxis marxista, em que a ação humana se dá de forma contextualizada e transformadora.

Na introdução da Contribuição à crítica da Filosofia do Direito de Hegel, Marx reafirma a necessidade de uma crítica à religião, e acrescenta que após se esclarecer a origem e o fundamento do mundo celeste, é preciso elucidar o que se pode estabelecer por verdade no mundo terrestre, material, concreto: "a religião é de fato a autoconsciência e o sentimento de si do homem, que, ou não se encontrou ainda ou voltou a perder-se. Mas o homem não é um ser abstrato, acocorado fora do mundo".

O conceito de não-alibi de Bakhtin pode ser associado ao que Marx afirma nos Manuscritos econômico-filosóficos (2010, p. 127) acerca da inexistência de um ser natural que não esteja em relação com o objeto (ser) exterior. Marx identifica o homem como um ser natural que apresenta forças naturais que o tornam ativo. Tais forças são identificadas como "possibilidades e capacidades [...] pulsões", mas que se faz limitado posto que os objetos de suas pulsões existem de forma independente, fora do ser. Esses objetos são necessários a sua existência, "indispensáveis para atuação e confirmação de suas forças essenciais".

Assumido que o homem é um ser vivo, efetivamente, ele só pode ter objetos efetivos como objeto de seu próprio ser, "que ele pode somente manifestar sua vida em objetos sensíveis efetivos”. Utiliza-se da metáfora da fome e do sol para explicar essa complexa relação:

A fome é uma carência natural; ela necessita, por conseguinte, de uma natureza fora de si, de um objeto fora de si, para se satisfazer, para se saciar A fome é a carência confessada de meu corpo por um objeto existente fora 
dele, indispensável à sua integração e externação essencial. 0 sol é o objeto da planta, um objeto para ela imprescindível, confirmador de sua vida, assim como a planta é objeto do sol, enquanto externação da força evocadora da vida do sol, da força essencial objetiva do sol (MARX, 2010, p. 127).

Assim é que se apresenta em Marx uma reflexão que pode ser associada ao não-álibi do ser, tornando aparente as bases dialéticas (materialistas) dessa proposta. Isso porque não pode existir um ser objetivo que não esteja inserido na relação de objetivação; não há um ser na natureza que não esteja em relação com objeto fora dele e que seja para outro objeto externo.

Um ser que não tenha sua natureza fora de si não é nenhum ser natural, não toma parte na essência da natureza. Um ser que não tenha nenhum objeto fora de si não é nenhum ser objetivo. Um ser que não seja ele mesmo objeto para um terceiro ser não tem nenhum ser para seu objeto, isto é, não se comporta objetivamente, seu ser não é nenhum [ser] objetivo. Um ser não objetivo é um não-ser (MARX, 2010, p. 127).

Argumenta-se ainda que, além de ser natural, o homem é também um ser humano e enquanto tal existe para si próprio, de forma genérica. Como ser genérico, o homem deve confirmar-se como ser e em seu saber. Por conseguinte, os objetos humanos não são os da natureza, mas os forjados na história, posto que é esta o ato de gênese humana.

Enquanto Marx e Engels demonstram a necessidade de relações entre os seres para a formação da consciência, Bakhtin apresenta a inserção social pela alteridade do ato humano. Para Bakhtin, o sujeito é social responsável, o autor da palavra plena, carregada de valor, de atitude perante o objeto e o contexto, a parte fundadora da sociedade. A alteridade, assim entendida, torna-se relação essencial do pensamento, do ato, da existência humana, portanto da linguagem, do enunciado. Marx; Engels e Bakhtin fundamentam a sociedade nas relações humanas e aproximam a linguagem - formação da consciência em Marx e Engels - de tais relações e suas contradições.
Bakhtin/Volochinov, a respeito dos contatos entre os homens, assevera que o centro organizador da expressão é exterior: "Não é a atividade mental que organiza a expressão, mas, ao contrário, é a expressão que organiza a atividade mental, que modela e determina sua orientação". Não se pode pensar a linguagem sem a existência e troca entre dois ou mais indivíduos, tornando a linguagem um produto social em sua origem e existência (BAKHTIN/VOLOCHINOV 1929/2010, p. 116).

Segundo Marx e Engels (2012), é a partir da divisão do trabalho material e espiritual que se torna possível uma dada autonomia de representação para a consciência. É nesse momento que a consciência diferencia-se ou distancia-se da práxis, dando origem à teoria, à teologia, à filosofia de forma pura. No entanto, argumenta-se a favor de uma relação sempre determinada pela materialidade das relações possíveis.

A produção de ideias, de representações, da consciência, está, em princípio, imediatamente entrelaçada com a atividade material dos homens, com a linguagem da vida real. [...] 0 mesmo vale para a produção espiritual, tal como ela se apresenta na linguagem da política, das leis, da moral, da religião, da metafísica etc. de um povo. Os homens são os produtores de suas representações, suas ideias e assim por diante, mas os homens reais, ativos, tal como são condicionados por um determinado desenvolvimento de suas forças produtivas e pelo intercâmbio que a ele corresponde, até chegar as suas formações mais desenvolvidas (MARX e ENGELS, 2012, p. 94).

Os autores delimitam, assim, o que entendem por intercâmbio, a saber: a própria sociedade civil, iniciada na família e ampliada conforme as necessidades. É a sociedade civil o foco de toda a história humana. Nesse sentido, outro aspecto do ato humano, para Marx e Engels (2012, p. 39) - o trabalho -, deve ser ponderado. Até o momento, a elaboração apresentada elucida aspectos do trabalho dos indivíduos sobre a natureza, mas há outro, pensado pelos filósofos em estudo, que parece contribuir para o cotejamento 
de ideias proposto nesta reflexão: é "o trabalho dos homens sobre os homens" que esclarece a produção "espiritual" humana.

Retomando o texto Para uma filosofia do ato (1929/2010), se pode depreender que a constituição do outro depende da minha singularidade. O lugar produtor de sentido é justamente onde ocorre a articulação de diferenças; é no confronto da minha singularidade que não coincide com o outro e a sua própria singularidade que se faz o sentido das singularidades em si. Assim, alteridade e subjetividade são a outra face do ato-pensamento. E a responsabilidade do ser, frente ao outro singular e ao outro universal, pode ser associada ao todo social de Marx e Engels. Também em Bakhtin, se compreende que o singular e o universal dependem da responsabilidade do ser e do ato de cada um para existirem, assim como em Marx e Engels que se observa a sociedade como construção coletiva e a existência de uma consciência una, que ganha status de ser social.

Para Bakhtin, o mundo real do ato é resultado dos confrontos e relações do eu, do outro e do eu para os outros. O ato humano é constituído em sua essência pela relação com o outro. O valor axiológico da ação humana é delimitado por essa mesma relação.

A proposta de Marx e Engels esclarece ainda que na análise dos atos humanos

[...] não se parte daquilo que os homens dizem, imaginam ou representam, tampouco dos homens pensados, imaginados e representados para, a partir daí, chegar aos homens de carne e osso; parte-se dos homens realmente ativos e, a partir de seu processo de vida real, expõe-se também o desenvolvimento dos reflexos ideológicos e dos ecos desse processo de vida (MARX e ENGELS, 2012, p. 94).

Para esses autores, os homens encontram-se objetivados em sua práxis, no trabalho, na atividade humana: "Tal como os indivíduos exteriorizam sua vida, assim são eles" (MARX e ENGELS, 2012, p. 87). Mas de fato o que esta objetivação do ser em seu trabalho pode significar ao que interessa a este trabalho, a alteridade? Vejamos: 0 homem se utiliza da natureza como meio no qual o seu trabalho se efetiva. A natureza é então o meio de vida da atividade humana trabalho, mas também é meio de existência do próprio trabalhador, posto que, sem tais meios, não estaria garantida a existência física do trabalhador nas atividades mais básicas: comer, beber, procriar etc.

Para entendermos de fato a alteridade intrínseca ao ato humano e, portanto, em nossa abordagem, à linguagem, é preciso partir da premissa de que o homem é um ser genérico, conformativo de espécie. Para Marx, o homem é um ser genérico e consciente, no momento mesmo em que faz da sua atividade vital - trabalho - a objetivação e transformação da natureza uma relação dele consigo em essência - ser genérico. É na objetivação que o homem se confirma como ser genérico.

[...] na elaboração do mundo objetivo [é que] o homem se confirma, em primeiro lugar efetivamente, como ser genérico. Esta produção é a sua vida genérica produtiva. [...] 0 objeto do trabalho é portanto a objetivação da vida genérica do homem: quando o homem se duplica não apenas na consciência, intelectualmente, mas operativa, efetivamente, contemplando-se por isso, a si mesmo num mundo criado por ele. Consequentemente, quando arranca do homem o objeto de sua produção, o trabalho estranhado arranca-lhe sua vida genérica, sua efetiva objetividade genérica e transforma a sua vantagem com relação ao animal na desvantagem de lhe ser tirado o seu corpo inorgânico, a natureza (MARX e ENGELS, 2012, p. 85).

O que ocorre é que com o estranhamento do trabalho, ou seja, o fato de o homem não reconhecer-se no trabalho, mas sim o outro, é que o homem estranha a si próprio. "Quando o homem está frente a si mesmo, defronta-se com ele o outro homem" (MARX e ENGELS, 2012, p. 86). Assim, o trabalho em si é produto de relação do homem consigo mesmo e com os outros. Estar estranhado ao ser genérico significa estar estranho aos outros homens e em relação a si próprio, da essência humana. 
Em geral, a questão de que o homem está estranho do seu ser genérico quer dizer que um homem está estranhado do outro, assim como cada um deles está estranhado da essência humana. 0 estranhamento do homem, em geral toda a relação na qual o homem está diante de si mesmo, é primeiramente efetivado, se expressa, na relação em que o homem está para com o outro homem. Na relação do trabalho estranhado, cada homem considera, portanto, o outro segundo o critério e a relação na qual ele mesmo se encontra como trabalhador. [...] Se minha própria atividade não me pertence, é uma atividade estranha, forçada, a quem ela pertence, então? A outro ser que não eu (MARX, 2010, p. 86).

Ao passo que a atividade não pertence ao eu, mas ao outro, se esclarece como o outro é constituidor do eu. Como também não pode ser totalmente estranha, toma por base o próprio eu para reconhecer no estranhamento o outro. Logo é uma relação recíproca de constituir-se como ser na relação possível de seu lugar único com o outro.

Para Marx (2010), vale lembrar, a relação do homem consigo mesmo lhe é primeiramente objetivada, efetiva, pela sua relação com o outro homem. Pensado dessa forma, a essência humana está na práxis de transformar a natureza em relação a si mesmo e aos demais. Por assim dizer, se dá vinculada em um princípio de alteridade, efetivado nas relações de comunicação, posto que advém da atividade consciente, como se afirmou anteriormente. Logo se observa que os sujeitos só podem estar a cada momento sendo forjados na própria alteridade de sua existência. $\mathrm{O}$ estranhamento só existe porque cada ato está enredado em fios ideológicos que se fazem presentes na própria objetivação do ser.

\section{A constituição dialógica do enunciado}

No capítulo $O$ discurso em Dostoievski, da obra Problemas da Poética de Dostoievski, Bakhtin esclarece que as relações dialógicas são extralinguísticas, dado que dizem respeito ao estudo metalinguístico. Assume que tais relações estão imbricadas no campo do discurso, “ou seja, da língua enquanto fenômeno integral concreto" (BAKHTIN/VOLOCHINOV, 1929/2010, s/d. p. 158).

A linguagem vive apenas na comunicação dialógica daqueles que a usam. É precisamente essa comunicação dialógica que constitui o verdadeiro campo da vida da linguagem. Toda a vida da linguagem seja qual for o seu campo de emprego (a linguagem cotidiana, a prática, a científica, a artística, etc.), está impregnado de relações dialógicas (BAKHTIN/VOLOCHINOV, 1929/2010, p. 158-159).

A dimensão dialógica delimita várias propriedades do enunciado concreto, já que este deve ser tomado como unidade real, concreta, da comunicação verbal. "[...] o todo do enunciado se constitui como tal graças a elementos extralinguísticos (dialógicos), e este todo está vinculado aos outros enunciados" (BAKHTIN/VOLOCHINOV, 1929/2010, p. 335-336).

Assim definido, mais uma vez se pode constatar que o enunciado constitui um ato humano, que, por isso, não pode ser compreendido fora de um contexto que tome por base as relações dialógicas que o constituem. "O ato humano é um texto potencial e não pode ser compreendido (na qualidade de ato humano distinto da ação física) fora do contexto dialógico de seu tempo (em que figura como réplica, posição de sentido, sistema de motivação)" (BAKHTIN, 1929/2010, p. 335).

O estudo científico do enunciado deve dedicar-se a revelar as relações dialógicas estabelecidas entre esta unidade e suas manifestações mais ou menos estáveis, incluindo aspectos extralinguísticos que se encontram refletidos no que o Círculo irá definir como - gêneros discursivos. Nesse sentido, a investigação se situa em área de alcance mútuo, tanto deve dizer respeito ao constructo teórico abstrato de enunciado isolado, quanto ao enunciado concreto e, por isso, dialógico. 
As relações dialógicas são irredutíveis às relações lógicas ou às concretosemânticas, que por si mesmas carecem de momento dialógico. Devem personificar-se na linguagem, tornar-se enunciados, converter-se em posições de diferentes sujeitos expressas na linguagem para que entre elas possam surgir relações dialógicas (BAKHTIN/VOLOCHINOV, 1929/2010, p. 159).

O enfoque dialógico permeia o íntimo do enunciado ou mesmo de uma palavra isolada em dado enunciado, desde que esta seja representante de posição interpretativa na cadeia de signos materializados, tornando-se, portanto, um enunciado em si. De outro modo, abarca, de igual forma, o contínuo de enunciados, estabelecendo-se tanto entre estilos de linguagem, dialetos sociais etc. como também frente à própria enunciação como um todo, com partes isoladas que possam trazer a presença do outro. A dimensão dialógica torna-se assim presença fundadora do enunciado, tão constituidora ou determinante quanto a alteridade.

Torna-se importante elucidar o que de fato faz parte da denominação diálogo nas abordagens do Círculo de Bakhtin. O diálogo deve ser visto como inconcluso. Há duas perspectivas temporais para o diálogo: a primeira e mais evidente é o diálogo em sentido estrito, ocorrido em um determinado tempo e espaço; a segunda diz respeito a um tempo histórico ilimitado.

O discurso, para Bakhtin (1934/35, p. 71), é um "fenômeno social em todas as esferas de sua existência" e é constituído de diversas vozes da vida social, ideologicamente situadas e que não perdem sua forma e conteúdo dentro do novo discurso. 0 discurso efetivo é o resultado da interação de vozes em concorrência, que, ao se interseccionarem, criam variados efeitos de sentido.

Marx e Engels nesse aspecto asseveram que:

As representações que [esses] indivíduos produzem são representações, seja sobre sua relação com a natureza, seja sobre suas relações entre si ou sobre sua própria condição natural. É claro que, em todos esses casos, essas representações são uma expressão consciente - real ou ilusória - de suas verdadeiras relações e atividades, de sua produção, de seu intercâmbio, de sua organização social e política (MARX e ENGELS, 2012, p. 93).

Percebemos em Marx e Engels características do caráter dialógico, ao admitir que toda representação advém de relações entre os indivíduos e a natureza. Nessas relações, que constituem a práxis, o sujeito se constrói a si próprio na intersubjetividade com o outro. Isso notadamente traz imbricada a relação de alteridade pensada pelo Círculo de Bakhtin. Alteridade e dialogismo encontram-se imbricados na própria identidade do ser. É na relação dialógica entre autor, destinatário e sobredestinatário que tem origem a formação da identidade, atravessada pela alteridade.

Todo enunciado apresenta autor em tempo e espaço que destina sua produção verbal a um destinatário que pode ser mais ou menos concreto e concebido com um variado grau de consciência. $\mathrm{O}$ que o autor de qualquer enunciado espera desse destinatário é uma atitude/compreensão responsiva. No entanto, este mesmo autor/criador pressupõe, em seu ato de criar, um superdestinatário superior, a quem Bakhtin denomina de terceiro elemento constitutivo do enunciado, "cuja compreensão responsiva, absolutamente exata é pressuposta seja num espaço metafísico, seja num tempo histórico afastado".

Bakhtin (2011, p. 357) ainda esclarece que o outro, neste caso, não é o segundo elemento do diálogo, outro sujeito ou discurso, mas sim um terceiro elemento que se mostra sempre superior e imanente ao ato verbal: "O fato de ser ouvido, por si só, estabelece uma relação dialógica. A palavra quer ser ouvida, compreendida, respondida, e quer, por sua vez, responder a resposta, e assim ad infinitum".

$\mathrm{Na}$ busca pela aproximação com o pensamento dialético-materialista retomemos Marx e Engels (2012), que, em Ideologia alemã, não pretendem um estudo esmiuçado acerca da linguagem, mas chamam atenção para 
o seu surgimento em contexto de interação social. A linguagem nasce na necessidade de relações do ser humano, na precisão do diálogo em uma compreensão que implica também a alteridade, outra característica do fenômeno linguístico discutida em Bakhtin, já estudada neste trabalho. Nas palavras de Marx, “a consciência da necessidade de estabelecer relações com os indivíduos que o circundam é o começo da consciência que o homem vive em sociedade" (MARX E ENGELS, 2012, p. 44).

Assim, a linguagem, para Marx, tem sua origem na necessidade dos seres humanos comunicarem-se, na interação social, portanto. A função da linguagem, nesse sentido, é de representar o que há na consciência dos homens e estabelecer os vínculos da comunicação entre eles. Consciência e linguagem se permeiam em uma relação dialética, na qual o homem sofre influência na e pela linguagem ao relacionar-se socialmente, e a influencia quando altera a realidade concreta por suas atitudes e ações conscientes.

[...] a consciência [...] é desde o início um produto social, e continuará sendo enquanto existirem homens. A consciência é, naturalmente, antes de mais nada mera consciência do meio sensível mais próximo e consciência da conexão limitada com outras pessoas e coisas situadas fora do indivíduo que se torna consciente [...] (MARX e ENGELS, 2012, p. 43).

Assumida a premissa de que a linguagem é uma exteriorização do espírito do homem, e que este espírito é, igualmente, constituído de linguagem desde o início de sua existência, então devemos admitir que a linguagem é o "instrumental" pelo qual a realidade material e objetiva influencia e, nas palavras de Marx, "determina", a consciência e, consequentemente, a vida dos homens organizados socialmente. Conforme se pode ler em Marx e Engels (2012):

O espírito tem de antemão a maldição de estar "preso" à matéria, a qual nos surge aqui na forma de camadas de ar em movimento, de sons, numa palavra, da linguagem. A linguagem é tão velha como a consciência - a linguagem é a consciência real e prática que existe também para os outros homens [...] (p. 43).
A linguagem é tão antiga quanto a consciência - a linguagem é a consciência real, prática, que existe também para os outros homens, que existe, portanto, também primeiro para mim mesmo e, exatamente como consciência, a linguagem só aparece com a carência, com a necessidade dos intercâmbios entre os homens (p. 34)

Para os dois pensadores são as condições materiais do ser humano que produzem consciência, nunca o contrário, como se pode observar em propostas idealistas. Assim, o ser humano apresenta como parte fundadora de sua essência a capacidade de produzir seu alimento, do que seria o desenvolvimento de sua consciência. Logo, a ontologia do trabalho, como transformação da natureza, é a base mesma do pensamento marxista.

0 modo através do qual os homens produzem seus víveres depende, em primeira mão, da própria constituição dos víveres encontrados na natureza e daqueles a serem produzidos. Esse modo de produção (Weise der Produktion) não deve ser observado apenas sob o ponto de vista que faz dele a reprodução da existência física dos indivíduos. Ele é, muito antes, uma forma, determinada de expressar sua vida, uma forma de vida determinada do mesmo. Assim como os indivíduos expressam sua vida, assim eles também são. 0 que eles são coincide com sua produção, tanto com o que eles produzem. 0 que os indivíduos são, portanto, depende das condições matérias de sua produção (MARX e ENGELS, 2012, p. 42)

Pensada dessa forma, a linguagem, também em Marx, pressupõe uma inter-relação permanente que pode ser associada ao dialogismo, em especial entre discursos e sujeitos que agem na organização, transformação, social. o contexto social de interação é igualmente o berço da linguagem. 0 diálogo aqui não aparece tão bem delimitado ou especificado quanto em Bakhtin/Volochinov, no entanto, se mostra em relação dialética posto que estabelece uma relação de influência recíproca e ininterrupta, manifestando os princípios de que (1) Tudo se relaciona e (2) Tudo se transforma. 


\section{A constituição ideológica do enunciado}

Bakhtin/Volochinov(1929/2010) defende que, ao lado da materialidade fenomenológica, coexiste um universo de signos, com caráter ideológico. Segundo essa proposta, qualquer objeto real pode se converter em signo e adquirir um sentido que ultrapasse os limites utilitaristas desse objeto. Assume-se, nesse texto, o caráter dual do signo, como parte de uma realidade, e também como reflexo e refração de uma outra. O signo pode tanto apreender a realidade como distorcê-la, pois, sendo ideológico, está sujeito a avaliações de verdadeiro, falso, correto etc. O processo de compreensão de um signo corresponde a ligações possíveis com outros signos, tornando-se atitude responsiva que converte signos em novos signos. Há uma cadeia de criatividade e compreensão ideológica que ocorre em nível semiótico que se mantém na realidade material do ponto de vista que pertence à natureza material corporificada em signos.

A cadeia ideológica é formada pelos elos entre as consciências individuais no processo de interação. Reconhece-se por outro lado o caráter retroalimentador, posto que a própria consciência individual é repleta de signos. É no processo de interação entre consciências que se forma cada uma das consciências.

Entender a consciência individual como um fato socioideológico é fundamental para a abordagem do signo linguístico, já que o material sígnico é a materialidade da consciência, estando ambas, consciência e linguagem, portanto, calcados na mesma origem social. Bakhtin/Volochinov argumenta ainda que a consciência só pode ser definida objetivamente como componente socioideológico, não podendo esconder-se no rótulo do subjetivismo individual e nem tão pouco ser considerada mecanicamente produto derivado da natureza.
Assim, os textos elaborados pelo Círculo, estudados neste trabalho, questionam a proposta positivista e a idealista que pretendiam derivar a ideologia da consciência. Cada grupo social organiza suas relações com base em sua própria criação sígnica, a qual se configura como a matéria mesma do desenvolvimento da consciência. A consciência individual reflete a lógica da comunicação social.

A consciência adquire forma e existência nos signos criados por um grupo organizado no curso de relações sociais. Os signos são alimento da consciência individual, a matéria de seu desenvolvimento, e ela reflete sua lógica e suas leis. A lógica da consciência é a lógica da comunicação ideológica, da interação semiótica de um grupo social. Se privarmos a consciência de seu conteúdo semiótico e ideológico, não sobra nada. A imagem, a palavra, o gesto significante, etc. constituem seu único abrigo. Fora desse material, há apenas o simples ato fisiológico, não esclarecido pela consciência, desprovido do sentido que os signos lhe conferem (BAKHTIN/VOLOCHINOV, 1929/2010, p. 36).

Para Bakhtin/Volochinov, a ideologia corresponde a uma realidade objetiva de signos que é reflexo das leis de comunicação semiótica e que por sua vez está determinada pelas relações possíveis em dada estrutura socioeconômica. A consciência individual encontra-se nesses termos vinculada ao conjunto dos signos ideológicos.

A realidade dos fenômenos ideológicos é a realidade objetiva dos signos sociais. As leis dessa realidade são as leis da comunicação semiótica e são diretamente determinadas pelo conjunto das leis sociais e econômicas. A realidade ideológica é uma superestrutura situada imediatamente acima da base econômica. A consciência individual não é arquiteto dessa superestrutura ideológica, mas apenas um inquilino do edifício social dos signos ideológicos (BAKHTIN/VOLOCHINOV, 1929/2010, p. 36).

Os autores procuram delimitar e definir o conceito de palavra, apresentando-a como elemento fortemente representativo do fenômeno superestrutural da ideologia, argumentando em favor da importância do 
estudo da linguagem para os estudos da ideologia e da consciência. "É, precisamente, na palavra que melhor se revelam as formas básicas, as formas ideológicas gerais da comunicação semiótica" (BAKHTIN/VOLOCHINOV, 1929/2010, p. 37).

Esclarece ainda algumas características da palavra que são consideradas de suma importância para a relação que se quer estabelecer entre a palavra, a consciência e a ideologia. A primeira delas é a neutralidade provisória e abstrata enquanto signo, que determina que a palavra possa servir a qualquer espécie de função ideológica, estética, científica, moral, religiosa, enquanto que os demais sistemas de signos permanecem vinculados cada um a domínios específicos.

Importante esclarecer que a neutralidade diz respeito a uma potencialidade da palavra enquanto abstrata. Não se pode pensar que essa neutralidade seria absoluta em qualquer momento de concretização da palavra, uma vez que, ao se tornar ato concreto, está sempre carregada de valor. A segunda característica da palavra diz respeito ao seu caráter primário. A palavra é produzida pelos próprios meios do organismo individual, não requerendo, portanto, nenhuma espécie de material extracorporal. Isso determina que seja a palavra "o material semiótico da vida interior, da consciência” (BAKHTIN/VOLOCHINOV, 1929/2010, p. 37).

Na verdade, a consciência não poderia se desenvolver se não dispusesse de um material flexível, veiculável pelo corpo. E a palavra constitui exatamente esse tipo de material. A palavra é, por assim dizer, utilizável como signo interior; pode funcionar como signo sem expressão externa. (BAKHTIN/VOLOCHINOV, 1929/2010, p. 37).

Decorre dessa abordagem, a necessidade de uma compreensão e um estudo da palavra como signo social e instrumento da consciência, posto que isso determina que a palavra acompanhe toda a criação ideológica.
Nenhum processo de compreensão ideológica ocorre sem a participação de um discurso interior. Nenhum outro sistema de signos pode ser substituído por palavras, mas esta acompanha e apoia a comunicação semiótica dos demais signos.

Como se pode ler em Marxismo e filosofia da linguagem, "Toda refração ideológica do ser em processo de formação, seja qual for a natureza de seu material significante, é acompanhada de uma refração ideológica verbal, como fenômeno obrigatoriamente concomitante" (BAKHTIN/VOLOCHINOV, 1929/2010, p. 38).

Admitir o caráter ideológico do signo implica assumir que a linguagem é elemento fundamental para explicar a relação entre a infraestrutura e a superestrutura. Como se pode definir tais relações? Como superar uma abordagem mecanicista, de reflexo direto, entre a infra e a superestrutura? Qual o papel da filosofia da linguagem na construção dessa abordagem? São essas perguntas que parecem nortear os escritos do Capítulo 2 de Marxismo e filosofia da linguagem.

O que torna essa proposta uma abordagem dialética é o caráter de ubiquidade social da palavra, o qual determina que esta seja um material privilegiado para se desvelar a relação de reciprocidade da infraestrutura e a superestrutura ou a materialidade e a ideologia correspondente.

No contato com os sistemas ideológicos instituídos está o nível superior da ideologia do cotidiano, que se mostra mais sensível que os sistemas e capaz de refletir as mudanças da infraestrutura de forma mais rápida. É neste nível que devem se acumular as "energias criadoras" pelas quais se efetivam paulatinamente mudanças nos sistemas ideológicos. Ressaltamos que, no próprio curso para chegar aos sistemas instituídos, a ideologia do cotidiano, ainda que em seu nível superior, sofre as influências das instituições ideológicas. Assim, o que se poderia pensar individual, é, na verdade, o 
núcleo da "orientação social do indivíduo" (BAKHTIN/VOLOCHINOV, 1929/ 2010, p. 125).

Uma possível aproximação das concepções do Círculo e a concepção dialético-materialista da realidade se encontra no fato de que, para esta última, o sujeito é sempre dimensionado em sua concretude, é considerado o criador da realidade social em que está inserido, sendo concomitantemente criado por tal realidade. A dialética materialista distancia-se de uma compreensão do ser humano como abstração e descarta a ideia de que a realidade possa ser desenvolvida pela especulação substancialista do homem. A práxis, ou atividade humana sensível, torna-se assim o mote para a compreensão dialética do homem enquanto ser social. Para Marx e Engels, “[...] cada geração, por um lado, continua o modo de atividade que lhe é transmitido, mas em circunstâncias radicalmente transformadas, e, por outro lado, ela modifica as antigas circunstâncias entregando-se a uma atividade radicalmente diferente"( MARX e ENGELS, 2012, p. 47).

Uma questão apresentada por Marx/Engels que contribui com os esclarecimentos neste trabalho é a ligação intrínseca entre a realidade social e a esfera econômica. $\mathrm{O}$ ato humano de produzir a vida, seja pela procriação ou pelo trabalho, é concebido em seu aspecto de relação natural e em sua dimensão social. Marx/Engels entende este social como sendo uma ação conjugada de vários indivíduos.

Na perspectiva dialética, todas as dimensões da vida social encontram-se em conexão formando uma realidade social somente possível na estrutura econômica, posto que é esta esfera que permite uma dada unidade da realidade social. Assim, é possível admitir que a dialética concebe o ser humano como sujeito que cria sua própria realidade social ao transformar a natureza por força de seu trabalho. A economia é nessa realidade a principal estrutura em que se torna possível a objetivação do ser.
A primazia da economia e a concepção do homem como sujeito social são premissas fundadoras do conceito materialista-dialético. Marx afirma que, no exame da sociedade burguesa, se verifica que é ela própria, a sociedade, que se apresenta como resultado do processo social de produção. Ou seja, o próprio homem em suas relações sociais é, em última instância, resultado do processo de produção do qual ele mesmo é objetivador (KOSIK, 1976/ 1985, p. 195).

Com base nessas considerações, se pode concluir que o mundo da abstração, da ideia, é igualmente um seguimento social de produção. As ideias são, nessa perspectiva, vistas como uma criação de seres humanos que se constituem em relações sociais concretas. Marx desmitifica a autonomia das ideias para torná-las produtos históricos de homens que com estas fazem a história da humanidade.

[...] para se considerar também o universo das ideias um seguimento do processo social de produção. Sem dúvida, as ideias podem ser vistas, então, como uma criação específica de homens que se constituem em relações concretas. Assim, elas perdem sua aparente autonomia para se tornarem produtos históricos de homens que, ao mesmo tempo, fazem a história (MARX/ENGELS, 2012, p. 85).

Para Marx e Engels, o homem está inserido em seu contexto de tal forma que se torna produto das relações sociais que o cercam. Nenhum ato de pensamento pode existir sem que carregue nele próprio o reflexo da existência real do homem, que, em última instância, se constitui pelas relações de trabalho ou práxis. A linguagem, ao apresentar um vínculo indissolúvel com as ideias e representações, está ela também determinada pelos meios de produção, o que vai surgir também nas elaborações do Círculo.

Para Bakhtin, a ideologia tem sua fundamentação material na palavra. É a palavra o meio pelo qual se pode perceber as mudanças quantitativas seguidas pelas qualitativas que acabam por tomar forma na superestrutura 
em sistemas ideológicos bem-formados. "A palavra é capaz de registrar as fases transitórias mais íntimas, mais efêmeras das mudanças sociais" (BAKHTIN/VOLOCHINOV (1929/2010, p. 42).

\section{A unidade das partes no todo - os gêneros discursivos}

Entendemos que por uma abordagem dos gêneros do discurso se pode esclarecer como de fato se dá a expressão da realidade e da contradição social na linguagem, ou seja, como a realidade se reflete e refrata na linguagem. No entanto, dada a exigência de aprofundamento desse tópico, optamos por suprimi-lo neste texto.

\section{Algumas considerações}

No processo de releitura e ressignificação das obras em questão, arriscamos um olhar que considerou a construção teórica da dialética materialista, construída em diálogo com Ideologia alemã, de Marx e Engels; Manuscritos econômico-filosóficos, de Marx. As obras foram selecionadas por serem reconhecidamente a base filosófica da dialética como forma de abordagem da realidade. Admitimos a necessidade de ampliação das obras filosóficas, mas assumimos os limites de leitura para área do conhecimento tão diversa de nossa formação, complexa e de sentidos dialógicos profundos, ao passo que se insere em um contínuo de elaboração marcado pela dimensão de tempo e de espaço, refletida nos conceitos teóricos e nas práticas metodológicas.

Assim sendo, esta pesquisa traz uma reflexão inicial a partir do nosso ponto de vista de formação linguística acerca das relações possíveis entre os conceitos linguísticos e uma dada abordagem bakhtiniana da linguagem e os pressupostos filosóficos, que em nosso entendimento delimitam a própria teoria de Bakhtin e seus pares. É necessário esclarecer que não pretendemos com essa discussão delegar o pensamento bakhtiniano a um enquadramento teórico limitador, nem tampouco proceder a associações indevidas ou desnecessárias. Argumentamos que qualquer processo que pretenda limitar ou vincular a escrita do Círculo não pode contribuir para o desvelamento do significado e dos valores axiológicos envolvidos nos trabalhos dos estudiosos do Círculo.

\section{Referências}

BAKHTIN, Mikhail. Problemas da Poética de Dostoievski. Trad. de Paulo Bezerra. Rio de Janeiro: ForenseUniversitária, 2010 (1929).

\section{_. Para uma filosofia do ato. São Paulo: Martins Fontes, 2003 (1920/1924).}

BAKHTIN/VOLOCHINOV Marxismo e filosofia a linguagem: problemas fundamentais do método sociológico na ciência da linguagem. Trad. Michel Lahud e Yara Frateschi Vieira. São Paulo: Hucitec, 2010 (1929).

GADOTTI, Moacir. Concepção dialética da educação. São Paulo: Cortez, 1995.

HOLQUIST, Michael; CLARK, Katerina. Mikail Bakhtin. São Paulo: Perspectiva, 1998.

KOSIK, Karel. Dialética do concreto. São Paulo: Paz e Terra, 1985.

LUKÁCS, Georg. História e Consciência de Classe. São Paulo: PCUS, 1960. Disponível em: http://www. marxists.org/portugues/lukacs/1920/consciencia/index.htm

MARX, Karl. Manuscritos econômico-filosóficos. Trad. de Jesus Ranieri. São Paulo: Boitempo, 2010.

MARX/ENGELS. A ideologia alemã. Trad. de Rubens Enderli et al. São Paulo: Boitempo Fontes, 2012.

Recebido em 09/11/2015

Aceito em 04/01/2016. 